\title{
Edward Stawasz"
}

\section{ROLA DORADZTWA GOSPODARCZEGO W ZARZĄDZANIU W MIKROPRZEDSIĘBIORSTWACH}

\begin{abstract}
Streszczenie
Prezentowany artykuł poświęcono omówieniu roli doradztwa gospodarczego w zarządzaniu mikroprzedsiębiorstwami. Opisano determinanty i znaczenie doradztwa gospodarczego jako czynnika wpływającego na niwelowanie luki w zakresie wiedzy zarządczej w mikroprzedsiębiorstwach. W drugiej części artykułu przedstawiono wyniki badań empirycznych 145 mikroprzedsiębiorstw korzystających z usług doradztwa gospodarczego w zakresie tworzenia wiedzy oraz formułowania strategii zarządzania w polskich mikroprzedsiębiorstwach.
\end{abstract}

Słowa kluczowe: sektor mikroprzedsiębiorstw, wiedza z zakresu zarządzania, doradztwo gospodarcze

\section{Wprowadzenie}

Podmioty gospodarcze małej skali posiadają wiele specyficznych charakterystyk rynkowych, finansowych, lokalizacyjnych, organizacyjnych i technologicznych, które określają ich operacyjne i strategiczne zachowania. W odróżnieniu od dużych firm większość małych podmiotów znajduje się w fazach początkowej (zaistnienia) i przeżycia, a tylko część z nich osiąga sukces, stając się firmą większą, stabilną lub firmą ekspansywną. W miarę rozwoju firma staje

* Edward Stawasz, dr hab. prof. UŁ, Uniwersytet Łódzki, Wydział Zarządzania, e-mail: stawasz@uni.lodz.pl 
w obliczu nowych problemów i wyzwań, barier i czynników ryzyka. W literaturze poświęconej zarządzaniu w sektorze MSP wymienia się coraz częściej doradztwo jako formę wsparcia zewnętrznego dla rozwoju przedsiębiorstw ${ }^{2}$. Pozwala ona w radzeniu sobie z pojawiającymi się barierami czy minimalizowaniu ryzyk w postaci wsparcia finansowego, infrastrukturalnego, technologicznego, usług szkoleniowych, doradztwa gospodarczego itp. Ostatni rodzaj wsparcia jest uważany za istotny czynnik poprawy zarządzania zwłaszcza podmiotów o najmniejszej skali (mikroprzedsiębiorstw), zarówno w obszarze redukcji barier ich rozwoju, jak i w dziedzinie zarządzania ryzykiem. Problem roli doradztwa gospodarczego dla tych podmiotów jest wciąż niedostatecznie rozpoznany w literaturze przedmiotu ${ }^{3}$. $Z$ tego powodu istotne jest spojrzenie na rolę doradztwa gospodarczego w tworzeniu wiedzy z zakresu zarządzania jako źródła redukującego bariery i wpływającego na kształtowanie prorozwojowej orientacji mikroprzedsiębiorstw.

Celem artykułu jest omówienie roli doradztwa gospodarczego w zarządzaniu mikroprzedsiębiorstwami. Opisano determinanty i znaczenie doradztwa gospodarczego jako czynnika prorozwojowego w przedsiębiorstwach. W drugiej części artykułu przedstawiono wyniki badań empirycznych dotyczących wpływu doradztwa gospodarczego na tworzenie wiedzy oraz formułowanie strategii rozwoju w polskich mikroprzedsiębiorstwach.

\section{Doradztwo gospodarcze a tworzenie wiedzy i strategia rozwoju w mi- kroprzedsiębiorstwach}

Miarą rozwoju współczesnych mikroprzedsiębiorstw jest ich zdolność do świadomego redukowania barier i minimalizowania ryzyk. Zjawisko to jest pozytywnie związane ze skalą przedsiębiorstw i fazy ich rozwoju. W literaturze

1 K. Wach, Otoczenie biznesu a fazy rozwoju matych i średnich przedsiębiorstw, Zeszyty Naukowe nr 769, Uniwersytet Ekonomiczny w Krakowie, Kraków 2008, s. 41-54.

2 J. Tuszyński, Doradztwo gospodarcze dla malych i mikroprzedsiębiorstw $w$ Polsce na przykładzie województwa śląskiego, maszynopis powielony, Wydział Zarządzania Uniwersytetu Łódzkiego, Łódź 2013.

3 J. Tuszyński J., op. cit., s. 83; L.M. Dyer, Ch.A. Ross, Advising the Small Business Client, „International Small Business Journal” 2007, Vol. 25, No. 2, s. 130-151; C. Suszyński, Ksztaltowanie strategii matych $i$ średnich przedsiębiorstw $w$ świetle badań nad wykorzystaniem zewnętrznych doradców przez krajowe MSP, w: Zarządzanie strategiczne. Strategie matych firm, red. R. Krupski, Prace Naukowe Wałbrzyskiej Wyższej Szkoły Zarządzania i Przedsiębiorczości, Seria: Zarządzanie i Marketing, Wałbrzych 2005, s. 94; P.J.A. Robson, R.J. Bennett, The Use and Impact of Business Advice by SMEs in Britain: an Empirical Assessment Using Logit and Ordered Logit Model, „Applied Economics” 2000, Vol. 32, No. 13, s. 1675-1688. 
podkreśla się, że wraz ze wzrostem skali przedsiębiorstw i ich dojrzałości rozwojowej poprzez wzrost ich zasobów i zdolności, następuje pewien spadek znaczenia barier w rozwoju ${ }^{4}$. W konsekwencji spada ryzyko podejmowanych przez przedsiębiorstwa projektów gospodarczych do poziomu ryzyka typowego dla danej branży czy regionu działania przedsiębiorstw, niezależnie od skali przedsiębiorstw5 $w^{5}$. Pozytywną rolę w procesie osłabiania barier rozwoju i redukcji ryzyka w mikro- i małych przedsiębiorstwach może odgrywać wsparcie zewnętrzne w postaci wsparcia finansowego, infrastrukturalnego, technologicznego, usług szkoleniowych, doradztwa gospodarczego itp. Przyczyniając się do wzrostu zasobów i zdolności przedsiębiorstw, wsparcie zewnętrzne, w tym doradztwo gospodarcze, pełni tutaj funkcję akceleratora w procesie kształtowania prorozwojowej orientacji mikroprzedsiębiorstw. Im większa jest skala i zakres wsparcia zewnętrznego, tym bardziej słabnie znaczenie barier w rozwoju przedsiębiorstw ${ }^{6}$. Budowa zdolności przedsiębiorstw do absorpcji wsparcia zewnętrznego może być zatem czynnikiem wspomagającym ich rozwój.

Doradztwo gospodarcze może mieć istotny wpływ na zarządzanie i rozwijanie mikroprzedsiębiorstw. Zarządzający mikorprzedsiębiorstwami rzadko dysponują całą wiedzą niezbędną do efektywnego, prowadzonego z sukcesem biznesu? Potrzebna i deficytowa wiedza może zostać pozyskana $z$ otoczenia, od doradców, w postaci profesjonalnej i niezależnej usługi mającej na celu pomaganie zarządzającym i przedsiębiorstwom w realizowaniu ich celów poprzez: rozwiązywanie problemów z sferze zarządzania, identyfikowanie i wykorzystywane nowych szans, uczenie się i wdrażanie zmian ${ }^{8}$. Według kryterium funkcjonalnego, doradztwo gospodarcze obejmuje doradztwo ogólne świadczone mniejszym przedsiębiorstwom, znajdującym się w początkowej fazie rozwoju, doradztwo funkcjonalno-zagadnieniowe oraz doradztwo specjalistyczne oferowane $\mathrm{z}$ reguły

${ }^{4}$ K. Łobacz, P. Głodek, Wpływ doradców biznesowych na decyzje $w$ zakresie realizacji projektów innowacyjnych $w$ MŚP - perspektywa europejska, Zeszyty Naukowe Uniwersytetu Szczecińskiego nr 714, Ekonomiczne Problemy Usług nr 90, Szczecin 2012, s. 11-30; K. Wach, op. cit., s. 41-54.

5 K. Łobacz, P. Głodek, op. cit., s. 11-30; J. Grande, E.L. Madsen, O.J. Borch, The Relationship between Resources, Entrepreneurial Orientation and Performance in Farm-based Ventures, „Entrepreneurship \& Regional Development” 2011, Vol. 23, No. 3-4, s. 89-111.

6 E. Stawasz, J. Ropęga, Barriers and Risk Factors in the Development of Micro and Small Businesses in Poland, w: International Entrepreneurship and Corporate Growth in Visegrad Countries, eds. A.S. Gubik, K. Wach, University of Miscolc, Miscolc 2014, s. 107.

7 B. Nogalski, T. Falencikowski, Zagadnienia epistemologiczne zarzadzania w mikroprzedsiębiorstwach, w: Zarzadzanie strategiczne..., s. 25-27.

8 Management Consulting. A Guide to the Profession, ed. M. Kubr, International Labour Office, Geneva 2002, s. 10. 
przedsiębiorstwom większym, dojrzałym. Natomiast według kryterium instytucjonalnego dzieli się na doradztwo wewnętrzne spotykane w dużych i dojrzałych przedsiębiorstwach oraz zewnętrzne, które jest usługą odpłatną lub nieodpłatną oferowaną przez wykwalifikowane i niezależne osoby fizyczne i prawne9.

Korzystanie z zewnętrznych usług doradczych przez mikroprzedsiębiorstwa jest koniecznością - może pomóc w pokonaniu licznych barier, przyczynić się do przetrwania oraz odniesienia rynkowego sukcesu ${ }^{10}$. Wynika to $\mathrm{z}$ faktu, iż posiadają one zasoby w niewielkiej i ograniczonej ilości, w tym zwłaszcza wiedzy i umiejętności oraz doświadczenia w zakresie zarządzania, które mają bezpośredni wpływ na trudności w rozwiązywaniu pojawiających się problemów ${ }^{11}$. Z tego powodu ważne jest pozyskiwanie ich z zewnątrz. $Z$ drugiej strony ograniczone zasoby własne przedsiębiorstw oraz niska jakość zarządzania, a także niska skłonność oraz ograniczona zdolność do absorpcji uzyskanej wiedzy, stanowią bariery w korzystaniu z usług doradczych ${ }^{12}$. Są one z reguły dużo wyższe w mikroprzedsiębiorstwach niż w przypadku przedsiębiorstw o większej skali i mają głównie charakter wewnętrzny. Mikroprzedsiębiorstwa z powodu istniejących barier w ograniczonym stopniu są świadome możliwości korzystania $\mathrm{z}$ usług doradczych, dlatego przejawiają względem nich niewielkie zainteresowa$n e^{13}$. Istotne jest również to, iż osiągane przez przedsiębiorców korzyści w tych obszarach są dostrzegalne w krótkim okresie oraz to, że najczęściej mają one wymierny charakter finansowy. $Z$ tego względu korzystają głównie z tanich i łatwo dostępnych źródeł wiedzy o prowadzeniu działalności, wykorzystując przy tym różne kanały dostępu do wiedzy, m.in. znajomości prywatne, Internet, media oraz porady przedsiębiorstw, z którymi utrzymują już kontakty biznesowe.

Wśród determinant korzystania z usług doradczych przez mikroprzedsiębiorstwa istotny wpływ mają czynniki charakteryzujące osobowość zarządzającego (wykształcenie i wiek, pozycja w przedsiębiorstwie) oraz czynniki związane

9 L. Stecki, Consulting, t. I, Wydawnictwo „Dom Organizatora”, Toruń 1997, s. 51-55; K.F. Mole, R. Baldock, D. North, Who Takes Advice? Firm Size Threshold, Competence, Concerns and Informality in a Contingency Approach, ERC Research Paper nr 9, September 2013, s. 6-7.

10 A. Gill, N. Biger, Barriers to Small Business to Canada, „Journal of Small Business and Enterprise Development 2012, Vol. 19, No. 4, s. 656-668; Metody rozwiąywania problemów $w$ warunkach matego przedsiębiorstwa, red. J.A. Antoszkiewicz, Wydawnictwo Szkoły Głównej Handlowej, Warszawa 1999, s. 5.

11 A. Gill, N. Biger, op. cit., s. 656-668; C. Suszyński, op. cit., s. 94-95.

12 K. Mole, Business Advisers' Impact on SMEs, „International Small Business Journal” 2002, Issue 2, Vol. 20, s. 92-109; R.J. Bennett, C. Smith, The Selection and Control of Management Consultants by Small Business Clients, „International Small Business Journal“ 2004, Vol. 22, No. 5, s. 435-462.

13 E. Stawasz, J. Ropęga, op. cit., s. 108. 
z orientacją rozwojową (posiadanie strategii rozwoju, luka wiedzy, wiek, wielkość oraz forma prawna przedsiębiorstw). Czynniki te oraz ich wzajemne powiązania różnicują sektor mikroprzedsiębiorstw pod względem zakresu i intensywności korzystania z usług doradczych ${ }^{14}$.

Relacje między posiadaniem strategii rozwoju, luką w wiedzy z zakresu zarządzania a korzystaniem z usług doradczych mają charakter sprzężenia zwrotnego i w konsekwencji są istotnym elementem w kształtowaniu zakresu i intensywności korzystania $\mathrm{z}$ doradztwa gospodarczego dla mikroprzedsiębiorstw. Zależność między posiadaniem strategii rozwoju a wiedzą może wskazywać na duże znaczenie wiedzy zarządzających w tworzeniu strategii rozwoju. Silna zależność oznacza, iż do stworzenia strategii niezbędne jest posiadanie wiedzy z zakresu zarządzania. Z kolei korzystanie z doradztwa gospodarczego może pełnić w tym procesie trzy funkcje: 1) pozytywnie wpływać na zmniejszenie luki wiedzy z zakresu zarządzania, wspomagając pośrednio tworzenie strategii, 2) bezpośrednio uczestniczyć w tworzeniu strategii bądź 3) wspomagać zarządzających w tworzeniu strategii rozwoju. Istotne znaczenie ma tutaj świadomość zarządzających o roli usług doradczych w tym procesie. Rzutuje bowiem na zakres i intensywność włączenia usług doradczych do procesu zdobywania wiedzy i tworzenia strategii rozwoju ${ }^{15}$.

Jak przedstawiono powyżej, celem artykułu jest określenie roli doradztwa gospodarczego w zarządzaniu w kontekście wiedzy z zakresu zarządzania oraz strategii zarządzania w polskich mikroprzedsiębiorstwach. Model zależności przedstawiono na rysunku 1. W artykule postawiono dwie propozycje główne: doradztwo gospodarcze ma pozytywny wpływ na rozwój wiedzy z zakresu zarządzania, a wpływ ten rośnie wraz ze wzrostem oceny wiedzy przedsiębiorstw $\left(\mathrm{P}_{1}\right)$, doradztwo gospodarcze wpływa pozytywnie na formułowanie strategii rozwoju $\left(\mathrm{P}_{2}\right)$ oraz dwie propozycje pomocnicze: o pozytywnym wpływie wiedzy na formułowanie strategii zarządzania $\left(\mathrm{P}_{3 \mathrm{a}}\right)$, o moderującym wpływie doradztwa gospodarczego na relację wiedza - strategia rozwoju $\left(\mathrm{P}_{3 \mathrm{~b}}\right)$.

14 A.J. Berry, R. Sweeting, The Effect of Business Advisers on the Performance of SMEs, „Journal of Small Business and Enterprise Development” 2006, Vol. 13, No 1, s. 33-47; Przetrwanie i rozwój małych i średnich przedsiębiorstw, red. F. Bławat, Scientific Publishing Group, Gdańsk 2004, s. 43-44.

15 D.R. Soriano, The Impact of Consulting Service on Spanish Firms, „Journal of Small Business Management” 2003, Vol. 41, No. 4, s. 409-416. 


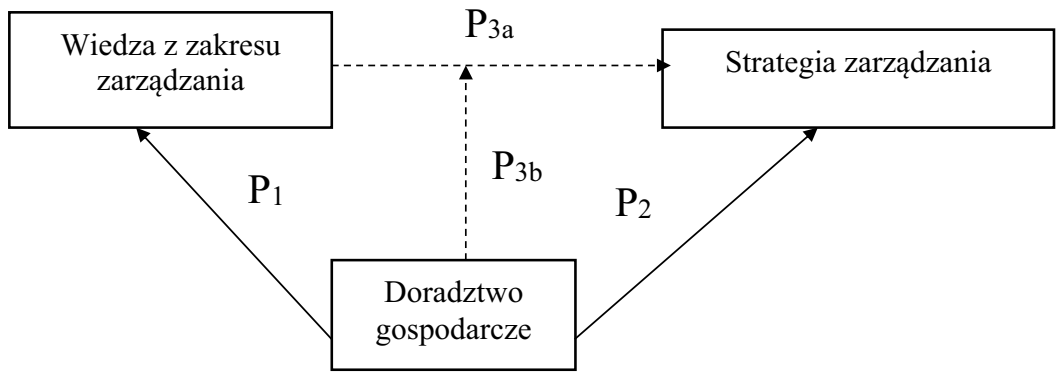

Rysunek 1. Proponowany model oddziaływań

Źródło: opracowanie własne.

\section{Wyniki postępowania badawczego}

\section{Charakter próby}

W artykule wykorzystano bazę 406 małych przedsiębiorstw działających na terenie całego kraju. Badanie było przeprowadzone z udziałem autora w 2012 roku w ramach projektu pt. „Doradztwo gospodarcze w mikroprzedsiębiorstwach”"16. Z usług doradczych korzystało w latach 2010-2012 łącznie 145 przedsiębiorstw, co stanowiło 35,9\% całości próby. Średnia wieku 145 badanych przedsiębiorstw wynosiła w 2012 roku 19,9 lat, czyli były to podmioty dojrzałe. Przeważały przedsiębiorstwa powyżej 10 lat obecności na rynku ( $80 \%$ badanej próby), zaś udział przedsiębiorstw nowych (do trzech lat działalności) wyniósł 4,1\%. Średnia wielkość zatrudnienia wynosiła 4,6 osób. Przeważały przedsiębiorstwa o liczbie pracujących od 2 do 5 osób, stanowiące 56,6\% całości próbki. Przedsiębiorstwa jednoosobowe stanowiły $13,1 \%$ badanej próby, a udział przedsiębiorstw o liczbie pracujących od 6 do 9 osób wynosił 30,3\%. Najliczniejszą grupę stanowiły przedsiębiorstwa usługowe $(74,5 \%)$, a w dalszej kolejności handlowe $(57,9 \%)$ i produkcyjne $(37,2 \%)$.

\section{Korzystanie z ustug doradczych}

W badanej próbie wszystkie mikroprzedsiębiorstwa korzystały w latach 2010 2012 z doradztwa gospodarczego. 8,3\% przedsiębiorstw korzystało wyłącznie z usług umownych, a 61,4\% z usług wyłącznie nieformalnych, zaś 30,3\% z usług zarówno formalnych, jak i nieformalnych. Jeśli chodzi o przedmiot uzyskanego doradztwa, 
to dotyczy ono przede wszystkim usług w zakresie marketingu i sprzedaży $(97,2 \%$ przedsiębiorstw), zarządzania strategicznego (91\%), a także zarządzania finansami (75,2\%), planowania i organizacji $(71,7 \%)$. W mniejszym stopniu w zakresie zarządzania produkcją i logistyką (38,6\%) oraz zarządzania personelem (37,9\%).

Najbardziej preferowaną formą korzystania z usług doradczych były rozmowy doradcze (95,9\% przedsiębiorstw) oraz kursy, szkolenia i treningi $(84,8 \%)$. W mniejszym stopniu dotyczyło to analiz i diagnoz $(72,4 \%)$ oraz całościowych projektów zmian $(42,1 \%)$, a więc usług bardziej kosztownych i trudniejszych do absorpcji w realiach mikroprzedsiębiorstw.

Spośród 145 mikroprzedsiębiorstw korzystających z usług doradczych tylko 27,6\% odnotowało wysoką skuteczność wykorzystania usług. Pozostałe 72,4\% przedsiębiorstw oceniło, że miały one słaby bądź żaden wpływ na poziom tworzenia wiedzy z zakresu zarządzania lub budowania strategii rozwoju, z tego $45 \%$ przedsiębiorstw uznało, że były one jedynie częściowo skuteczne, zaś 26,9\% przedsiębiorstw oceniło, iż były one nieskuteczne (tabela 1).

Tabela 1

Ocena skuteczności wykorzystania z usług doradczych*

\begin{tabular}{|l|c|}
\hline \multicolumn{1}{|c|}{ Wyszczególnienie } & w \% \\
\hline Skuteczne & 27,6 \\
Częściowo skuteczne & 45,5 \\
Nieskuteczne & 26,9 \\
\hline
\end{tabular}

*Dane dla 145 przedsiębiorstw

Źródło: opracowanie własne.

\section{Wiedza z zakresu zarządzania}

Za miernik oceny wiedzy z zakresu zarządzania przyjęto wskaźnik samooceny zarządzających w skali 1-5 pkt (gdzie 1 pkt oznaczał bardzo niski poziom wiedzy, zaś 5 pkt - bardzo wysoki poziom wiedzy). Średni poziom tego wskaźnika w badanej grupie był dość wysoki i wyniósł w 2012 roku 3,4 pkt, 11,7\% zarządzających posiada słabą wiedzę, po 41,4\% -wystarczającą lub dobrą, a 5,5\% bardzo dobrą (tabela 2). Dane powyższe wskazują na dobrą opinię zarządzających o ich umiejętnościach prowadzenia przedsiębiorstw. Związane jest to zapewne z wysokim (długoletnim) doświadczeniem zarządzających wynoszącym dla całej 
badanej próby 16,7 lat, jak i wysokim poziomem wykształcenia zarządzających (wykształcenie wyższe posiadało 64,1\% zarządzających).

Tabela 2

Rozkład oceny wiedzy z zakresu zarządzania (w samoocenie zarządzających)*

\begin{tabular}{|l|c|}
\hline \multicolumn{1}{|c|}{ Przedziały oceny wiedzy } & \% przedsiębiorstw \\
\hline Niska ocena (1-2 pkt) & 11,7 \\
Srednia ocena (3 pkt) & 41,4 \\
Wysoka ocena (4-5 pkt) & 46,9 \\
\hline
\end{tabular}

*Dane dla 145 przedsiębiorstw

Źródło: opracowanie własne.

\section{Strategia rozwoju}

Strategię rozwoju formalną bądź nieformalną zgodną z zasadami sztuki zarządzania, tj. określającą podstawowe cele przedsiębiorstw dla okresu co najmniej rocznego, posiadało $71 \%$ przedsiębiorstw. Pozostałe $29 \%$ nie posiadało strategii rozwoju. Zasadniczym celem zarządzających było przetrwanie przedsiębiorstwa, sprowadzające się do bieżącego prowadzenia przedsiębiorstw, reagowania na bieżące wyzwania, szanse bądź zagrożenia. W badanej próbie wystąpiło duże zróżnicowanie według wielkości przedsiębiorstw posiadających strategię rozwoju: 52,6\% przedsiębiorstw jednoosobowych, $68,3 \%$ przedsiębiorstw zatrudniających 2-5 osób oraz $84,1 \%$ przedsiębiorstw dla grupy o zatrudnieniu 6-9 osób (tabela 3).

Silne zróżnicowanie wystąpiło także, jeśli chodzi o wykształcenie zarządzających przedsiębiorstwami posiadającymi strategię rozwoju: $20 \%$ zarządzających z wykształceniem zasadniczym, 53,2\% zarządzających z wykształceniem średnim, $82,8 \%$ zarządzających z wykształceniem wyższym.

Tabela 3

Strategia rozwoju badanych przedsiębiorstw (odsetek posiadających)*

\begin{tabular}{|c|c|}
\hline Kategorie przedsiębiorstw według liczby zatrudnionych & \% przedsiębiorstw \\
\hline 1 & 52,6 \\
$2-5$ & 68,3 \\
$6-9$ & 84,1 \\
\hline
\end{tabular}

*Dane dla 145 przedsiębiorstw

Źródło: opracowanie własne. 


\section{Zależności}

W celu ustalenia wzajemnych zależności wiedzy, strategii rozwoju oraz doradztwa gospodarczego zastosowano unormowane współczynniki kontyngencji C Pearsona. Z przeprowadzonej analizy wynika, iż zależność między skutecznością usług doradczych a posiadaniem strategii rozwoju w badanej próbie jest słaba $(0,126)$ na poziomie istotności 0,3 . Wyraźna zależność wystąpiła między skutecznością usług doradczych a oceną wiedzy z zakresu zarządzania $(0,331)$ oraz oceną wiedzy z zakresu zarządzania i posiadaniem strategii rozwoju $(0,472)$ na poziomie istotności 0,01 (tabela 4). Można sformułować wniosek, iż do stworzenia strategii rozwoju niezbędne jest posiadanie wiedzy z zakresu zarządzania, a także, że korzystanie z usług doradczych w wyraźnym stopniu wpływa na kształtowanie wiedzy z zakresu zarządzania w badanych przedsiębiorstwach. Natomiast korzystanie $\mathrm{z}$ doradztwa gospodarczego nie wpływa bezpośrednio na tworzenie strategii rozwoju w badanych mikroprzedsiębiorstwach, co może oznaczać niską skuteczność usług doradczych w tym przypadku.

Tabela 4

\section{Zależności* $^{*}$}

\begin{tabular}{|l|c|c|c|}
\hline & Ocena wiedzy & $\begin{array}{c}\text { Posiadanie strategii } \\
\text { rozwoju }\end{array}$ & $\begin{array}{c}\text { Skuteczność usług } \\
\text { doradczych }\end{array}$ \\
\hline Ocena wiedzy & 1,000 & $0,472^{\mathrm{a}}$ & $0,331^{\mathrm{b}}$ \\
\hline Posiadanie strategii rozwoju & $0,472^{\mathrm{a}}$ & 1,000 & $0,126^{\mathrm{c}}$ \\
\hline $\begin{array}{l}\text { Skuteczność usług } \\
\text { doradczych }\end{array}$ & $0,331^{\mathrm{b}}$ & $0,126^{\mathrm{c}}$ & 1,000 \\
\hline
\end{tabular}

*Dane: dla 145 przedsiębiorstw; a-poziom istotności 0,$01 ; \mathrm{b}$ - poziom istotności 0,01 ; c-poziom istotności 0,3 .

Źródło: opracowanie własne.

Bardziej pogłębiony obraz relacji między skutecznością usług doradczych a oceną wiedzy zarządzających pokazuje rozkład odpowiedzi przedsiębiorstw (tabela 5). Wynika z niego, iż grupa zarządzających o najwyższym poziomie wiedzy z zakresu zarządzania najwyżej ocenia przydatność doradztwa gospodarczego dla powiększania zasobu wiedzy. Może to także świadczyć o stosunkowo dobrym wykorzystaniu usług doradczych przez tę grupę zarządzających. 
Wiedza zarządzających a skuteczność doradztwa gospodarczego*

\begin{tabular}{|l|c|}
\hline \multicolumn{1}{|c|}{ Przedziały oceny wiedzy zarządzających } & \% przedsiębiorstw \\
& z wysoką oceną skuteczności doradztwa \\
\hline Niska ocena (1-2 pkt) & 23,5 \\
Średnia ocena (3 pkt) & 20,0 \\
Wysoka ocena (4-5 pkt) & 35,3 \\
\hline
\end{tabular}

*Dane dla 145 przedsiębiorstw

Źródło: opracowanie własne.

Z przeprowadzonych badań wynika, iż w obszarze orientacji prorozwojowej mikroprzedsiębiorstw łączącej się z pokonywaniem barier rozwoju im wyższy jest poziom wiedzy z zakresu zarządzania i wykształcenia zarządzających (poziom wiedzy i poziom wykształcenia zarządzających jest silnie powiązany), tym częściej korzystają one z doradztwa i tym częściej posiadają strategię. Silna korelacja między posiadaniem strategii rozwoju a wiedzą z zakresu zarządzania może oznaczać bowiem, iż zarządzający mają świadomość, że do stworzenia strategii niezbędne jest posiadanie wiedzy. Powyższa zależność jest istotnym elementem w kształtowaniu procesu doradczego dla mikroprzedsiębiorstw ${ }^{17}$.

Wydaje się, że w analizowanym przypadku poziom wiedzy zarządzających jest koniecznym i istotnym warunkiem tworzenia strategii rozwoju, natomiast wsparcie ze strony doradztwa gospodarczego pełni rolę uzupełniającą, wspomagając zmniejszanie luki wiedzy zarządzających poprzez kumulację wiedzy. Samo doradztwo gospodarcze bez rozwiniętej wiedzy zarządzających jest mało skutecznym instrumentem w kształtowaniu orientacji rozwojowej badanych przedsiębiorstw.

Dla testowania zależności o moderującym wpływie doradztwa gospodarczego na relację wiedza - strategia rozwoju (propozycja $\mathrm{P}_{3 \mathrm{~b}}$ ) oszacowano parametry następującego modelu probitowego:

$$
\begin{gathered}
S_{i}^{*}=\alpha_{0}+\alpha_{1} W_{i} 1\left\{D_{i}=0\right\}+\alpha_{2} W_{i} 1\left\{D_{i}=1\right\}+\alpha_{3} W_{i} 1\left\{D_{i}=2\right\}+\varepsilon_{i}, \\
\varepsilon_{i} \sim N(0,1), S_{i}=1\left\{S_{i}^{*} \geq 0\right\},
\end{gathered}
$$

gdzie:

$S_{i}$ - zmienna zero-jedynkowa przyjmująca wartość 1 dla przedsiębiorstw posiadających strategię,

$W_{i}$ - zmienna oznaczająca ocenę wiedzy z zakresu zarządzania, 
$D_{i}$ - zmienna oznaczająca ocenę skuteczności doradztwa gospodarczego.

W wyniku estymacji uzyskano następujące wyniki:

Model 1. Estymacja Probit, wykorzystane obserwacje 1-145

Zmienna zależna: strategia rozwoju

$$
\text { Współczynnik błąd standardowy } \quad \mathrm{z} \quad \text { wartość } p
$$

Const. $-2,94357$

Ocena wiedzy 0

1,12667

0,629678 $-4,675 \quad 2,94 \mathrm{e}-06 * * *$

Ocena wiedzy 1

1,05461

0,226992

4,963

$6,92 \mathrm{e}-07$

0,190140

$5,546 \quad 2,91 \mathrm{e}-08$

Ocena wiedzy 2

1,04899

0,193072

$5,433 \quad 5,54 \mathrm{e}-08$

Następnie testowano następującą hipotezę zerową:

$$
\alpha_{1}=\alpha_{2}, \quad \alpha_{2}=\alpha_{3},
$$

za pomocą testu Walda i uzyskano następujący wynik:

statystyka testu: $\operatorname{chi}^{\wedge} 2(2)=0,603946, \mathrm{z}$ wartością $p=0,739358$

Oznacza to zatem, że przyjmując poziom istotności 0.05 , nie ma podstaw do odrzucenia hipotezy zerowej mówiącej o braku moderującego wpływ doradztwa gospodarczego na relację: wiedza - strategia rozwoju. Powyższy wynik potwierdza wcześniejszą konkluzję o niskiej skuteczności usług doradczych w procesie tworzenia strategii rozwoju w badanych mikroprzedsiębiorstwach, zarówno w bezpośrednim, samodzielnym wpływaniu na orientację rozwojową przedsiębiorstw, jak i w przypadku wspomagania zarządzających w procesie tworzenia strategii rozwoju.

\section{Podsumowanie}

Analiza rezultatów badań przeprowadzonych w grupie mikroprzedsiębiorstw potwierdza propozycję $\mathrm{P}_{2} \mathrm{o}$ zależności między korzystaniem $\mathrm{z}$ usług doradczych a posiadaniem strategii rozwoju. Zależność ta $\mathrm{w}$ badanej próbie była słaba, nieistotna. W bardzo ograniczonym stopniu wystąpiła zależność: im większe wsparcie w postaci usług doradczych, tym większy zakres posiadanej 
przez przedsiębiorstwa strategii rozwoju. Nie potwierdzono także propozycji $\mathrm{P}_{3 b}$ o moderującym wpływie doradztwa gospodarczego na relację wiedza - strategia rozwoju. Natomiast istotne zależności wystąpiły pomiędzy korzystaniem z usług doradczych a oceną wiedzy zarządzających oraz oceną wiedzy zarządzających i posiadaniem strategii rozwoju. Potwierdziło to propozycje $\mathrm{P}_{1}$ oraz $\mathrm{P}_{3 \mathrm{a}}$. Można sformułować wniosek, iż doradztwo gospodarcze istotnie wpływa na kształtowanie poziomu wiedzy zarządzających, a także, że poziom wiedzy zarządzających w wyraźnym stopniu wpływa na orientację rozwojową przedsiębiorstw.

Wydaje się, że w układzie wiedza - strategia - doradztwo gospodarcze kluczową rolę odgrywa poziom wiedzy zarządzających - jest on koniecznym $\mathrm{i}$ istotnym warunkiem tworzenia strategii rozwoju i jest niezbędny w kształtowaniu zapotrzebowania na doradztwo gospodarcze. Doradztwo to może odgrywać: 1) ważną rolę przy budowie wiedzy, zwłaszcza w grupie zarządzających o najwyższym poziomie wiedzy z zakresu zarządzania oraz 2) rolę uzupełniającą dla kształtowania orientacji rozwojowej mikroprzedsiębiorstw, wspomagając zmniejszanie luki wiedzy zarządzających poprzez powiększanie zasobu wiedzy. Samo doradztwo gospodarcze bez rozwiniętej wiedzy zarządzających jest mało skutecznym instrumentem, tak w bezpośrednim kształtowaniu orientacji rozwojowej mikroprzedsiębiorstw, jak i pośrednio, w przypadku wspomagania zarządzających w procesie tworzenia strategii rozwoju. Skuteczność doradztwa gospodarczego wymaga zatem zaawansowanej wiedzy zarządzających jako warunku jej wykorzystania oraz uzyskania wysokiego poziomu orientacji rozwojowej mikroprzedsiębiorstw.

\section{Literatura}

Bennett R.J., Smith C., The Selection and Control of Management Consultants by Small Business Clients, „International Small Business Journal” 2004, Vol. 22, No 5.

Berry A.J., Sweeting R., The Effect of Business Advisers on the Performance of SMEs, „Journal of Small Business and Enterprise Development” 2006, Vol. 13, No 1.

Dyer L.M, Ross Ch.A., Advising the Small Business Client, „International Small Business Journal" 2007, Vol. 25, No. 2.

Gill A., Biger N., Barriers to Small Business to Canada, „Journal of Small Business and Enterprise Development" 2012, Vol. 19, No 4.

Grande J., Madsen E.L., Borch O.J., The Relationship between Resources, Entrepreneurial Orientation and Performance in Farm-based Ventures, „Entrepreneurship \& Regional Development” 2011, Vol. 23, No 3-4. 
Łobacz K., Głodek P., Wpływ doradców biznesowych na decyzje w zakresie realizacji projektów innowacyjnych w MŚP - perspektywa europejska, Zeszyty Naukowe Uniwersytetu Szczecińskiego nr 714, Ekonomiczne Problemy Usług nr 90, Szczecin 2012.

Management Consulting. A Guide to the Profession, ed. M. Kubr, International Labour Office, Geneva 2002.

Lundström A., Almerud M., Stevenson L., Entrepreneurship and Innovation Policies. Analysies Measuring in European Countries, Swedish Foundation For Small Business Research, Orebro 2008.

Metody rozwiązywania problemów $w$ warunkach małego przedsiębiorstwa, red. J.A. Antoszkiewicz, Wydawnictwo Szkoły Głównej Handlowej, Warszawa 1999.

Mole K., Business Advisers' Impact on SMEs, „International Small Business Journal” 2002, Issue 2, Vol. 20.

Mole K.F., Baldock R., North D., Who Takes Advice? Firm Size Threshold, Competence, Concerns and Informality in a Contingency Approach, „ERC Research Paper”, No. 9, September 2013.

Nogalski B., Falencikowski T., Zagadnienia epistemologiczne zarzadzania w mikroprzedsiębiorstwach, w: Zarządzanie strategiczne. Strategie matych firm, red. R. Krupski, Prace Naukowe Wałbrzyskiej Wyższej Szkoły Zarządzania i Przedsiębiorczości, Seria: Zarządzanie i Marketing, Wałbrzych 2005.

Przetrwanie $i$ rozwój małych i średnich przedsiębiorstw, red. F. Bławat, Scientific Publishing Group, Gdańsk 2004.

Robson P.J.A., Bennett R.J., The Use and Impact of Business Advice by SMEs in Britain: an Empirical Assessment Using Logit and Ordered Logit Model, „Applied Economics" 2000, Vol. 32, No. 13.

Soriano D.R., The Impact of Consulting Service on Spanish Firms, „Journal of Small Business Management" 2003, Vol. 41, No. 4.

Stawasz E., Ropęga J., Barriers and Risk Factors in the Development of Micro and Small Businesses in Poland, w: International Entrepreneurship and Corporate Growth in Visegrad Countries, eds. A.S. Gubik, K. Wach, University of Miscolc, Miscolc 2014.

Stecki L., Consulting, t. I, Wydawnictwo „Dom Organizatora”, Toruń 1997.

Suszyński C., Kształtowanie strategii małych i średnich przedsiębiorstw $w$ świetle badań nad wykorzystaniem zewnętrznych doradców przez krajowe MSP, w: Zarzadzanie strategiczne. Strategie małych firm, red. R. Krupski, Prace Naukowe Wałbrzyskiej Wyższej Szkoły Zarządzania i Przedsiębiorczości, Seria: Zarządzanie i Marketing, Wałbrzych 2005.

Tuszyński J., Doradztwo gospodarcze dla matych i mikroprzedsiębiorstw $w$ Polsce na przykładzie województwa śląskiego, maszynopis powielony, Wydział Zarządzania Uniwersytetu Łódzkiego, Łódź 2013.

Wach K., Otoczenie biznesu a fazy rozwoju malych i średnich przedsiębiorstw, Zeszyty Naukowe nr 769, Uniwersytet Ekonomiczny w Krakowie, Kraków 2008. 


\title{
THE ROLE OF BUSINESS CONSULTING IN THE MANAGEMENT OF MICRO-ENTERPRISES
}

\begin{abstract}
Summary
The paper presents the role of business consulting in the management of micro-enterprises. It discusses the importance of determinants and the impact of business consulting as a factor in reducing the gap in knowledge on management of micro-enterprises. The second part of the paper presents the results of empirical studies of 145 micro-enterprisesbenefiting from business consulting servicesin the field of knowledge creation and formulation of management strategies in Polish micro-enterprises.
\end{abstract}

Keywords: sector of micro-enterprises, knowledge on management, business consulting Translated by Bartosz Szukalski 